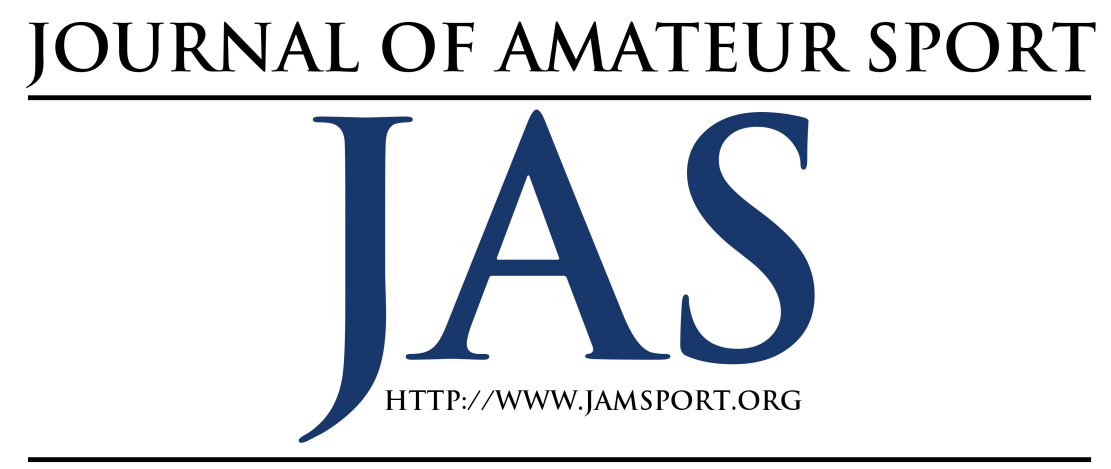

\title{
College Athletics Spending: Principals and Agents v. Arms Race
}

\author{
Rodney Fort \\ University of Michigan
}

\begin{abstract}
It is widely held that collegiate athletic directors are trapped in an expenditure arms race. But the arms race explanation completely omits the actual consideration of the university budgeting process. In its place, the arms race logic imposes strained assumptions about the cooperative setting and the naïvete of university administrators, along with a curious distinction of one type of revenue to reach its conclusions. And the interpretation of the data on spending and benefits from college sports has not been done particularly well in the past. This paper presents an alternative principal-agent explanation that is based on the observed actual financial (budget) relationship between university administrators and their athletic department and consistent with the entirety of the aggregate-level data on college athletics finance. Empirically discerning between the two models is crucial since each generates decidedly different policy implications.
\end{abstract}

I $\mathrm{t}$ is commonly held that college athletic directors (ADs) are trapped in an expenditure arms race. This arms race explanation (ARE) is so pervasive that it is now invoked casually in academic work and invoked in nearly every policy discussion of college athletics spending. The direct evidence taken in support of an arms race is rapidly escalating spending compared either to the general increase in prices or (and especially) compared to increases in spending on college academic programs. And inherent in that observation is that such spending is in excess of the value created.

This paper offers an alternative principal-agent explanation (PAE) on observed college athletics spending. Where the ARE ignores the university budgeting process entirely, instead choosing to cast ADs trapped in an arms race via a set of assumptions, the PAE is based directly on 
the actual relationship between university administrators (UAs) and their ADs.

The inspiration for this line of thinking came from two distinct literatures. Early on, there was a rejection of the ARE of predator-prey interaction in behavioral biology (Abrams, 1986). Later, Weingast \& Moran (1983) and Weingast (1984) rejected models following Niskanen (1971) that cast "runaway" bureaucrats in control of their own spending.

Of course, if strained assumptions give us the most analytical leverage over the observed outcome of college sports then they may be worth it. However, the PAE also turns the ARE observation that college sports are a net drain on the university budget on its head. Budget allocations by UAs to the athletic department are not "bail outs" but, instead, comparatively small investments in values across the rest of campus that both suit UA objectives and cover their costs.

Whether the ARE or the PAE is operative is critical because each dictates entirely different policy approaches. For any given level of college sports output, the ARE dictates that wasteful spending is occurring to achieve that level. The policy prescription is to cut the wasteful spending and still achieve the same level of sports output. On the other hand, for that same level of college sports output, the PAE dictates that the budget of the athletic department, including the infusion of funds from the university budget, is sufficient to insure that level of sports output for UAs. If the PAE is in operation, following the dictates of the ARE and cutting spending can only reduce the values that college sports creates 1) across campus, 2) for college sports consumers, and 3) for students competing in college sports.

This is not to argue that the level taken as given in this comparison is necessarily the socially preferred level. However, that level should be determined by its values and costs, not some possibly incorrect view that whatever level is determined, the process at the university will result in spending that is too high to achieve it. Determining which explanation, ARE or PAE, is in operation is essential to hitting whatever is the agreed upon target of college sports output.

This paper proceeds as follows. In Section II, the ARE as it currently is applied to college sports spending is presented. The descriptive PAE is offered in Section III. Section IV summarizes the comparison of the empirical veracity of the alternative explanations. Policy implications accompany the conclusions in Section V.

\section{The Arms Race Explanation}

Edwards' (1984, p. 7) reference to an athletic arms race in the recruiting and development of college athletes is the earliest I could find but an overview of just the most recent college sports "issues" journals reveals that the ARE is often now simply taken for granted. Weight, Navarro, Huffman, \& Smith-Ryan (2014, p. 394), in their paper on shifting governance and the 
value of participation, provide the most extensive statement:

This formal governance shift is troubling to some who believe it will hasten the arms race of extravagant expenditures...The arms race of expenditures represents a win-at-allcosts phenomenon wherein athletic administrators outspend one another...The arms race has been pursued at all levels of intercollegiate athletics but some of the most detrimental effects of the spending are most clearly evident at the Division I Power Five level... [Italics added.] In that same journal, just in the most recent volume, similar use of the arms race as a motivation for research is in Brewer, McEvoy, \& Pops (2014, p. 76); Sanderson, Hardin, \& Pate (2014, p. 127); Huml, Hancock, \& Bergman (2014, p. 425); and Cooper, Cavil, \& Cheeks (2014, p. 325). Some of these cite the earlier work by Tsitsos \& Nixon (2012) and Weight, Weight, \& Schneider (2013). Moving to the most recent issue of other sports "issues" journals, the list grows to include Sagas \& Wigley (2014, p. 49); Lanter \& Hawkins (2013, pp. 87-88); Staurowsky, Murray, Puzio, \& Quagliariello (2013, p. 111-112); Sparvero \& Warner (2013, pp. 123, 136); and Hoffer \& Pincin (2016, p. 84).

The ARE is also now gospel at the National Collegiate Athletic Association (NCAA), among watchdogs like the Drake Group and the Knight Commission on Intercollegiate Athletics (henceforth,
KCIA), and in popular media reports. The earliest statement I could find among this variety of adherents puts it clearly enough (KCIA, 2001):

The most glaring elements of the problems outlined in this report academic transgressions, a financial arms race, and commercialization - are all evidence of the widening chasm between higher education's ideals and big-time college sports... [Italics added.]

A time-series cross-section sample of the pervasiveness of this acceptance since then is KCIA (2009, 2010a, 2010b); Women's Sports Foundation (2008); Fuoco (2010); Stafflord (2010); Gurey (2014), and Drake Group (2015).

Analytical support of this view followed a few years later when KCIA commissioned Frank (2004) to provide an academic treatment (general economic coverage of arms races can be found in Arce \& Sandler, 2005, and Dixit, 2006, and their extensive reference sections). Frank started his presentation with what is surely the clearest motivation of the ARE, Shubik's (1971) dollar auction game. An auctioneer enforces a non-cooperative setting with no talking among participants. Then the auctioneer holds up a dollar bill and announces that it will be sold to the highest bidder and that the auctioneer will also collect the bid of the second highest bidder. The result is over-bidding relative to the size of the prize. Since the second highest bidder will receive nothing in return, it is always in their best 
interest to raise the bid even when the bidding exceeds one dollar. I can personally attest that the game produces precisely this result having used it for years myself as a teaching device.

Frank (2004) then makes the assumptions required and applies Shubik's (1971) logic directly to collegiate sports spending. College sports are assumed a noncooperative endeavor and Frank (2004) pays particular attention to the naïveté of UAs in estimating the probability of obtaining future values. Frank (2004) also assumes that all are chasing a fixed revenue prize and all are spending to chase it. According to Frank (2004), in such a setting it should be expected that more would be spent than the value created by college sports. The overspending is pure waste since the same prize could be had with less spending.

Frank (2004) offers empirical support of the ARE in two steps. First, he shows that the typical athletic department result is spending in excess of "generated" revenues.

"Generated" revenues include everything except the direct allocation by UAs from the general university budget to the athletic department budget. This latter allocation is typically referred to separately as "institutional support". Second, he surveys the work of others at the time and concludes that the returns college sports generate across the rest of the university (on-field success, student applications, or general giving to the university) cannot cover "institutional support".
Frank (2004) concludes that if all athletic departments were to simultaneously reduce and cap spending, exactly the same college sport outcomes would be achieved, in quantity and in quality. Then KCIA Chair William Friday (President Emeritus, UNCChapel Hill) said of Frank's findings (KCIA, 2004), "His study points to the need for an overall 'stand down' in the athletic funding 'arms race."'

\section{The Principal-Agent Explanation}

This section presents a descriptive model of the PAE. A model is just an abstraction that can be compared in its explanatory value to other models. In true economic fashion, the model here is neither heavily documented nor judged closely by its bearing on reality (although my limited experience suggests it does so). Indeed, those interested in testing the model in ways different from the tests in this paper may succeed in replacing it with something else. But for now, the model offered here offers both interesting insights and alternative policy prescriptions.

While there will be variations, a generally descriptive model of UAs and ADs can be based on the following elements of the observed nature of their environment. ADs operate in their university structure, their conference structure, and as one of the representatives of their university to the NCAA. In this setting, the relevant actors are UAs and their overseers (e.g., board of regents) and ADs. The process could be easily extended 
to include conference commissioners and NCAA administrators. All care about income and upward mobility that, in turn, enhances their future welfare. In the context of their environment, enhanced welfare depends upon the performance of their respective organizations in the eyes of their hierarchical overseers.

However, and this is a critical component, there can be areas of conflict between the goals of UAs and the selfinterested pursuits of ADs. The welfare of UAs depends on the performance of their agents along well-known dimensionsresearch, teaching, and service. While the definition of research and teaching are transparent, service may not be. Members of the university are engaged in free outreach, information to the press and participation in press events, and entertainment. On the latter, some might think of fine arts offerings, especially music and dance. College sports are clearly another entertainment, also offered by members of the university.

The ability of UAs to overcome conflicts with their agents in the provision of research, teaching, and service will depend on two things. First, ADs will consider the net value of independent action that is possibly detrimental to the welfare of UAs; the higher that net value, the more often UAs will expect ADs to attempt that independent course of action. Second, the costs of monitoring to UAs will temper the oversight mechanism choice and the level of that oversight.
This operational environment suggests a setting that is well known to economists, namely, UAs are "principals" to the "agents" in departments across campus (Ross, 1973; Jensen \& Meckling, 1976). The agents are academic leaders and nonacademic leaders like ADs. The president of the university in consultation with the board of regents (most typically, but with some exceptions) controls the AD's employment and pay subject to market forces and the costs of monitoring. Along this well-known line of reasoning, UAs have every incentive to create and manage institutional designs that harness the self-interested behavior of ADs to the enhancement of UA welfare. This is the essence of the PAE.

If output is predictable and observable at discrete points in time, direct, hierarchical monitoring is possible and effective. If not, incentive compatible devices where the agent shares in specified, direct ways (e.g., profit sharing) may prove more effective. In the university case, apparently output is predictable and observable since UAs handle all of their principal-agent relationships through hierarchical oversight with only trivial incentive compatible mechanisms (e.g., performance bonuses to ADs). UAs organize the university into departments so as to facilitate the comparative advantages of each department along the lines of research, teaching, and service as well as to facilitate monitoring.

The athletic-academic department design comparison is as follows. All of the assistant coaches in a given sport are 
specialists in different areas just like individual faculty on the academic side (e.g., in football, strength and conditioning, position coaches, offensive and defensive coordinators). These specialists are organized under the head coach similar to an academic department and its chair. The collection of sports is organized into the larger unit, the athletic department, similar to schools or colleges on the academic side.

To keep the analogy truly complete, we could refer to this as the "school of athletics" since, at the top of the athletic department, the $\mathrm{AD}$ is the equivalent of an academic dean (at least in terms of oversight and authority). The AD has associate ADs to handle the day-to-day operations of the department, freeing the $\mathrm{AD}$ to see to fund raising and external relations for the athletic department. The AD answers to the President (rather than the Provost on the academic side) and up the ladder to the board of regents and governor.

The ultimate result of this principalagent structure is money and political support that is useful to UAs pursuing their goals. Services from all areas of the university flow out, under the three major headings of research, teaching, and service, and money and political support come back to UAs. In turn, hierarchically, through Deans and directors, including athletic directors, UAs allocate rewards back to departments. As is the typical principalagent result, agents including ADs are rewarded when they contribute to UA goals and face the prospect of reduced resources at least, and demotion or unemployment at most, when they don't.

Some doubt the power that overseers have over UAs or, in turn, the power that UAs have over ADs because of observed major oversight breakdowns such as the Southern Methodist University football program death penalty imposed beginning with the 1988 football season or the recent Penn State sexual predator scandal. But the PAE explains this contingency - as long as monitoring is costly, and overseers act economically, there will be some transgressions that will not be caught until after the fact (if at all). We can all wish that it were not so, but it is. So just finding holes in any oversight process is not evidence against the PAE. And focusing on the holes misses the greater point-by and large the oversight process works.

If ADs do not contribute to UA goals, or if the athletic department becomes costly to the university in embarrassing ways, then UAs have recourse. For one, budget allocations to the athletic department can simply be reduced. Numerous examples where ADs reduced their budgets to meet university-wide reduction mandates by UAs during the recent economic downturn are presented by Cross (2015). Experience also reveals that budget cuts occur even without financial exigency. At the limiting extreme, there are interesting current and historical observations where King Football has simply been closed down altogether by UAs. But a careful case-by-case reading 
shows that it was never going belly-up in an arms race that was the cause.

Historically (tracking through the college football conference listings at the respected sports-reference.com), 6 Football Bowl Subdivision (FBS, Division I-A prior to 1978) football programs have been abolished-University of Chicago in 1939, Villanova in 1980 (although it returned a few years later at the Football Championship Subdivision, or FCS, level), CSU-Long Beach, CSU-Fullerton, and University of the Pacific in the 1990s, and Alabama-Birmingham in 2014. The Ivies and a few departments from the Southern Conference and Southland Conference also moved to the FCS in 1981.

Football was abolished at 54 FCS colleges (Division I-AA prior to 1978) starting in the 1920s and the most recent examples prove instructive of what causes this at this level of play. UAs at Northeastern University cut its football program in November of 2009 and UAs at Hofstra University followed suit the next month. The official stance at Northeastern was, "The decision is consistent with the university's strategic approach to prioritize programs and invest in signature strengths" (ESPN.com News Services, 2009a). At Hofstra, UAs stated flatly that football was eliminated because of a general lack of interest among students and alumni, and a desire to spend the money to greater advantage on academic programs (ESPN.com News Services, 2009b). No public mention can be found in either case that this had anything to do with being pushed to absurd spending levels and finally throwing up their hands a la the ARE.

There also are other dramatic actions familiar to all who follow collegiate sports that can be taken by UAs. Episodes of unsatisfactory performance and $\mathrm{AD}$ firings or forced resignations are well known and program quality blind. Just recently at two college sports icon programs, ADs David Brandon (Michigan) and Steve Patterson (Texas) began searches for new employment. Some might argue that the sway of coaches over the process is being glossed over. But if they hold such sway, it's interesting that the good ones change jobs often and are seldom happy with the actions of their UAs (historically, Bear Bryant; recently, Urban Meyer). And let's not forget that their tenure is beholden to their UAsa nice way of putting that they also are fired on a regular basis.

As with all things, not all departments are equally adept at each of the research, teaching, and service areas and an effective organizational structure would take this into account. Among academic departments, some are more about teaching and others are more about research. Compared to academic departments, the mix is different still for the athletic department. Although arguably there can be a research mission, there clearly is teaching (student athletes populate the coaching ranks and professional sports). But athletic departments truly shine in service (entertainment). 
The PAE also puts an entirely different spin on "institutional support", that is, the budget allocation to the athletic department. First, from the PAE perspective, all revenues to the athletic department are "generated," some at the gate and attendance related (parking and concessions), some from TV, some from booster contributions (alumni and others), and still others in terms of the budget allocation from the university. It is rational for UAs to allocate these rewards to highest possible return among all departments including the athletic department. Second, there is no difference in the purpose of budget allocations to the academic side and the allocation to the athletic department. All "agents" compete on the basis of their relative success in the eyes of their UA principals. Athletic departments receive their share, as do all departments, through a competitive budgeting process at the university level.

One final note concerns the actual functioning of budgeting. In all of the deliberations that lead to the final budget decisions of UAs, the purpose of the allocation is completely clear. As they do in all areas, UAs are attempting to see to the funding of an athletic department of optimal size and scope for their purpose. UAs then expect all departments to spend their entire budget to make good on the promises made during the battle for their budget share. As in all units on campus, it is expected that spending should equal all revenue, including the UA allocation.
Members of the athletic department, from the AD through the associate ADs, on down to coaches and assistants, and finally the athletes themselves, provide entertainment services enjoyed by millions. The returns to UAs include the direct money payment that comes through the tuition component of grants-in-aid to athletes. More typically, the benefits not found in the athletic department bottom line include (Fort \& Winfree, 2013):

- Greater giving by alumni and other boosters to the general university fund.

- A larger and better set of student applicants.

- Favorable general budget treatment by legislators.

- Better faculty and administrators.

- Value added to athletes, some of who would not be at the university without athletics.

The upshot of all of is a set of questions whose answers can separate the PAE from the ARE that are addressed in the next section:

1. Do ADs operate in a non-cooperative setting?

2. Are UAs and ADs naïve?

3. Is it tragic to come in second?

4. Does spending always rise to meet revenues?

5. Does the value created by the athletic department across the university provide a reasonable return on the instutional support investment? 


\section{Arms Race or Principals and Agents? Do ADs operate in a non-cooperative setting?}

While incentives can be in conflict at the university, cooperative behavior abounds at all levels of college sports organizations. Examples include AD cooperation through their conferences in determining membership, setting schedules and rules, hiring officials, and designing conference championships. Cooperation of this nature is required in order to define and brand conference play. Cooperation through conferences also results in conference TV contracts to the economic benefit of its members and, more recently, the creation of conference sports networks (e.g., the ACC Network, Big Ten Network, the SEC Network, and the Pac-12 Networks).

Moving up one level, in all sports except FBS football, ADs cooperate through their conferences and on up to the NCAA to determine national champions. The College Football Playoff that determines the FBS national champion is also a marvel of cooperation among "Power 5" conference commissioners that represent their individual conference members (Atlantic Coast Conference, Big 12, Big Ten, Southeastern, and Pacific-12), the sports network ESPN, and bowl organizers.

The NCAA controls applications to advance to higher divisions. The NCAA also is a cooperatively designated marketing manager of many sports properties (videos, image use in video games). Finally, the NCAA is used cooperatively to reduce the economically competitive urges that cannot be controlled by members in conferences alone. The member institutions of the NCAA created the amateur requirement, recruiting restrictions, required letters of intent, the one-year sit out rule, and all rules governing practice time. The office of the President of the NCAA enforces these rules.

Given this extensive structure of cooperation, it simply strains any sense of reality to suppose that ADs and their UAs act non-cooperatively.

\section{Are UAs and $\mathrm{ADs}$ naïve?}

Frank (2004) simply states that UAs are naïve, based on findings in unrelated research that some people have been observed to be naïve in some situations. However, to date, nobody has actually analyzed whether or not this is true of actors in collegiate sports and there is plenty of prima facie evidence to the contrary. All UAs and ADs "come up through the ranks;" they must satisfy relentless selection mechanisms. The result of such intense selection would typically be participants keenly aware of their environment and well trained for the job at hand.

UAs are seasoned administrators and observers of the collegiate sports scene. ADs are astute students of business, many are lawyers, and all cut their teeth on the collegiate sports scene. While first hand management at the top level will be new to all at first, and mistakes are human, the idea that they are naïve seems far-fetched. 
None of this would appear to the knowledgeable observer of sports management personnel to suggest any naiveté at all.

\section{Is it tragic to come in second?}

There is nothing at all to suggest that the fundamental underpinning of the ARE - that is, coming in second is truly tragic — characterizes college sports spending. "Tragic" in the ARE context means that all bidders pay but only one earns any return. While it is true that there is only one conference champion, and only one subsequent national champion, this is not "winning" in the ARE sense. All of the rest of the ADs also generate revenues and kudos for their competitive performances. Life is pretty good even for coaches and ADs at FBS institutions that seldom win their conference championship, let alone see post-season play. Nearly all of the athletic departments in Table 1 come in "second" nearly all the time but the revenue results appear to be far from tragic (shortly, it is made clear that there is nothing special about 2013-14 in this regard).

Indeed, there is demand to enter the top levels of competition where the arms race should be most heated, rather than avoid it. Four schools earned bona fide FBS membership in 2013-South Alabama, Texas State, Massachusetts, and Texas-San Antonio. Four more will establish full FBS membership rights in 2015-Old Dominion, Appalachian State, Georgia Southern, and North Carolina-Charlotte.
The UAs and ADs at these 8 recent entrants would all have to fall into the same trap under the ARE; that they were about to jump in to a long-established arms race situation, destined for tragedy.

There is nothing at all to suggest that the fundamental underpinning of the ARE, that is, coming in second is truly tragic, characterizes college sports spending.

\section{Does spending always rise to meet revenues?}

The PAE tells us ADs should spend all of their budgets, including allocations from UAs, so that revenues equal expenses. There would be no reason to expect any budget deficits other than for the usual mistakes under uncertainty because these would be in nobody's best interest. It should be noted in passing that annual operations ignore the possibility of an arms race in capital, a possibility raised by Orszag \& Orszag (2005a, 2005b). But the spending arms race is taken at large as a general explanation of spending.

The NCAA commissions an ongoing survey of operating revenues and expenses for athletic departments in the different divisions of college sports (most recently, Fulks, 2015). The data are presented in two forms in the original documents, the median report (average report before 2004) and the largest report. In any given year, neither of these reported aggregates necessarily matches up to the same athletic department; the average revenue reported does not necessarily come from the same athletic 
department that reports the average expenditure. But the NCAA finds this type of characterization of "average" and "large" programs useful so it is carried along here

Simply combining the revenue and expense data for the FBS into Figure 1 (I first found this useful in Fort, 2010) presents an aggregate picture of collegiate sport revenues and expenses that is entirely consistent with the PAE, but not the ARE. First, at the average report through 2003, revenues and expenditures both grew at the same 4.6 percent real (inflation adjusted) annual rate. At the median report from 2004 on, revenues and expenses grew at the same 5.6 percent real annual rate. Second, the correlation between revenue and expenses during the period of average reports is 1.00 and 0.99 during the period of median reports. Essentially, "average" athletic departments have enjoyed tremendous revenue growth and spend every dollar they bring in.

It is difficult to make any call on "net" revenue since the revenue and spending reports are not necessarily from the same department. In addition, there can be as much as a decade between the earliest reports (an examination across individual departments appears below). In any event, the largest excess of spending over revenue is 3 percent in 2014, at the median reports of the two.

For the largest reported values, the real annual growth in revenues and expenses (both are reported from 1985 on) is 5.5 percent and 5.1 percent, respectively. The correlation between revenues and expenses is 0.97. Unlike their "average" counterparts, the "largest" athletic departments don't spend quite everything they bring in, but it is close. The interesting dip in reported largest spending from 2001-2003 and the slighter deviation over the last five years could do with further analysis. Expenses exceed revenues only once in 1997 by 0.2 percent.

In passing, it is easy to see why some might view the increase in spending with alarm. The real annual growth rate in spending just noted at both the "average" and "largest" reports are large relative to the typical real growth rate in the economy. They are also large relative to the growth in spending on the academic side. However, worries about some form of collapse appear misplaced (Fort, 2010). The real annual growth rate in the average report of revenues, of course, matches the growth in expenses.

Consistent with the budget process on which the PAE is based, the median- and largest-reports show ADs spending all of their revenue, including institutional support. Of course, this level of aggregation begs a more disaggregated examination. That may be had using the USAToday (2015) data on individual department revenues and expenditures. This is a data base of high integrity, generated by Freedom of Information Act requests of individual athletic departments.

The results are in Tables 2 and 3 . Immediately, the correlations in Table 2 across all FBS departments tell the same 
story as the correlations over time for the median and largest reports in Figure 1. Essentially, departments spend every dollar they take in and this is true despite the broader variation from negative net revenues to positive. The only possible exception would be 2005-06, when Oklahoma State recorded the largest contribution in the entire data set, $\$ 211,023,155$, nearly twice the next largest (Oregon, \$124,927,474 in 2013-14). When that outlier is removed, the correlation climbs again to the usual level in Table 2, 0.983 .

As one would expect in cross-section, there is substantial variation around either the mean, median, or mode in any year. While the mode is always $\$ 0$, only more detailed analysis of the position of every department in the distribution over time can tell the story from that perspective on the propensity to break even. However, revealed in Table 3, between $21 \%$ and 33\% of the departments are within a quarter of a million dollars of $\$ 0$ in any of the tabled years.

Granted, revenues equal to expenditures could also be consistent with some other model of college sports outcomes not compared here. For example, Hoffer, Humphreys, Lacombe, \& Ruseski (2015) model athletic department spending and find that athletic departments spend all revenue and practice "non-price" competition in their spending decision. But this paper is long enough and a test of other models awaits both the specification of such an alternative test and the associated empirical work.

\section{Does the value created by the athletic department across the university provide a reasonable return on the instutional support investment?}

Frank (2004) read the literature on nonrevenue values from college sports one way, on a few dimensions (on-field success, student applications, or general giving to the university), and found them small at best. Without any formal comparison, he concluded that such small returns did not justify the level of institutional support.

Fort \& Winfree (2013, Chapter 3) detail how Frank's appeal to past work on the values of college sports at the university was cursory at best. The latest data available to them was for 2010-11, and for "Automatic Qualifier" (AQ) schools at the time of the data reviews. The AQ schools included what is now the FBS Power 5 plus the Big East Conference. There were 54 AQ reports in the popular source they used. The Power 5 would of course be the object of future analysis at this level. They demonstrate that the tuition part of the grant-in-aid to student athletes that is paid to the university provides ample return in all but six AQ cases.

For those remaining six, values across the rest of the university did not have to be very large, relative to the institutional support investment, in order to generate even a 5 percent return. A similar exercise revealed that the proportion of the rest of 
the FBS departments that needed to rely on the values across the rest of the university was larger than for the AQ case. However, the level of these values required to generate a reasonable return was only an issue at a very few schools. In addition, and contrary to some perceptions, the FCS ADs actually run their programs much more on a breakeven basis, program by program, than do their FBS counterparts.

Fort and Winfree (2013) also show that the variety of values created across the rest of the university was much broader than Frank (2004) examined, even in the literature available to him at the time of his writing. For example, the survey and extension in Goff (2004) revealed a broader array of values as well as some work touting higher values than those found by Frank (2004). In addition, Fort and Winfree (2013) point out that work since then has revealed that this value is also much higher than Frank concluded.

Humphreys \& Mondello (2007), Tucker (2004, 2005), Tucker \& Amato (2006), and Smith (2008) showed values from giving to the university rather than just the athletic department. Tucker $(2004,2005)$ also found football success increased the SAT scores of entering freshmen and enhanced graduation rates. Humphreys (2006) found that FBS football participation generated an 8 percent larger annual state appropriation than those without such programs. It should come as no surprise, then, that Fort and Winfree (2013) reach the opposite conclusion of Frank (2004). Even though each of the values may be small, in total the direct money payment via the tuition portion of grants-in-aid, plus the values across the rest of the university, are large enough to justify the institutional support investment made by UAs.

All of this is completely consistent with the level of institutional investment generating sufficient return consistent with the PAE but not with the ARE.

\section{Conclusions and Policy Observations}

The principal-agent explanation outperforms the arms race explanation both in terms of its description of the actual process (rather than strained assumptions) and in its application to data on college spending outcomes. As always, one study never decides any issue and additional work exploring these competing explanations is in order.

Formal development of the rigorous implications of the principal-agent explanation is surely needed in order to hone empirical propositions on college sports. The explanation should also be tested in other arenas. For example, the same type of data on revenue and expenses are available for Division II and Division III. Similar analysis to that done here for FBS universities can be done there in order to determine whether a principal-agent explanation generalizes to college sports where, ostensibly, big revenues appear not to be the goal. In another spending area, it could be that arms race logic is operational 
in other contexts such as capital investment covered by Orszag \& Orszag (2005b).

The principal-agent explanation should also be useful in university-athletics relationships beyond just the spending outcome. Surely a catastrophic failure of oversight led to the tragic sexual violence scandal at Penn State and the complete capture of the university vis a vis athletics in the SMU football death penalty episode. But the principal-agent logic also adds another consideration for the reformminded, namely, assessing how to improve those monitoring processes.

If it stands later scrutiny, the principalagent explanation offered here changes the focus of policy intervention from remedies aimed at outcomes, like spending reductions and caps, to institutional design. One important lesson from application of this explanation to bureaucratic processes is that principal-agent mechanisms afford principals chances to credit-claim and blame-shift (Weingast \& Moran, 1983; Weingast, 1984). On this dimension, blame shifting could be the explanation for survey reports by university administrators that they "feel powerless" to change collegiate sports (Knight Commission on Intercollegiate Athletics, 2009). This claim rings hollow in the face of a history replete with examples of them doing just that, but is consistent with blame shifting.

Another important principal-agent institutional design lessons is that effective oversight can generate complete alignment between the preferences of principals and the behavior of their agents, revealing that the stance of critics is not about oversight, but about the preferences of principals in the first place (Weingast \& Moran, 1983, and Weingast, 1984). If so, there is no principalagent problem. Instead, and completely legitimately, others can only disagree with the preferences, not the process. This is especially insightful to those constantly monitoring the mix of university outputs.

But there are important policy observations in this context as well. If the oversight process were working effectively, then instead of reducing waste, spending cuts and caps would produce a social loss. This loss would be in the form of reduced values created across the rest of the university, reduced satisfaction for those that enjoy the games, and, paradoxically, reduced satisfaction and future earnings for those students whose participation in college sports would be reduced. This may or may not be what critics seek, but it will be true nonetheless.

This is not to argue that the level of college sports output is necessarily the socially preferred level. However, that level should be determined by its values and costs, not by applying an arms race view that whatever level is determined, overspending will occur. Determining which explanation is in operation, arms race or principal-agent, is essential if the institution of college sports is to produce whatever is the agreed upon level of college sports output. 
According to the principal-agent explanation, if there is any problem with the level of athletic spending, it will be found in the "slack" in these levels of oversight - the choice of the level of spending on athletics by UAs is not at the level preferred by their overseers and/or there is a fundamental weakness in the oversight relationship between UAs and their AD principals. From the principal-agent perspective, one might see spending run away, but it is not "runaway spending" resulting from an arms race. And altering spending (after all, ineffective oversight might also allow overseers to underspend on athletics) would be only part of the remedy.

Without meaningful reform of the oversight process itself, any problem with the level of spending will not be solved. For example, while hierarchical monitoring and oversight work for academic deans, perhaps there are better approaches with ADs. Other incentive compatible approaches may be more valuable to university administrators, on net. 


\section{References}

Abrams, P.A. (1986). Adaptive responses of predator to prey and prey to predators: The failure of the arms race analogy. Evolution, 40, 12291247.

Arce, D.G., \& Sandler, M.T. (2005). The dilemma of the prisoners' dilemmas. Kyklos, 58, 3-24.

Brewer, R.M., McEvoy, C.D., \& Pops, N. (2014). Predicting intrinsic value of NCAA Division I men's basketball coaching salaries. Journal of Issues in Intercollegiate Athletics, 8, 74-91.

Cooper, J.N., Cavil, J.K., \& Cheeks, G. (2014). The state of intercollegiate athletics at historically black colleges and universities (HCBUs): Past, present, \& persistence. Journal of Issues in Intercollegiate Athletics, 7, 307-332.

Cross, M. (2015). Ultimate Sports Insider. Retrieved from http://www.ultimatesportsinsider.co $\mathrm{m}$.

Dixit, A. (2006). Thomas Schelling's contributions to game theory. Scandinavian Journal of Economics, 108, 213-229.

Drake Group. (2015). Position statement: Student fee and institutional subsidy allocations to fund intercollegiate athletics. March 2. Retrieved from https://drakegroupblog.files.wordpre ss.com/2015/04/position-statementstudent-fees-final-3-2-15.pdf.

Edwards, H. (1984). The collegiate athletic arms race: Origins and implications of the "Rule 48" controversy. Journal of Sport and Social Issues, 8, 4-22.

ESPN.com News Services. (2009a). Too costly, football done at Northeastern. November 30. Retrieved from http://sports.espn.go.com/boston/n $\mathrm{cf} /$ news $/$ story?id $=4681701$.

ESPN.com News Services. (2009b). Hofstra drops football after 69 seasons. December 3. Retrieved from http://sports.espn.go.com/ncf/news / story?id $=4709412$.

Fort, R. (2010). An economic look at the sustainability of FBS athletic departments. Journal of Intercollegiate Sport, 3, 3-21.

Fort, R., \& Winfree, J. (2013). 15 sports myths and why they're wrong. Stanford, CA: Stanford University Press.

Frank, R.H. (2004). Challenging the myth: A review of the links among college athletic success, dtudent quality, and donations. Knight Commission on Intercollegiate Athletics. May. Retrieved from http://www.knightcommission.org/i mages/pdfs/kcia_frank_report_2004. pdf.

Fulks, D.L. (2015). Revenues \& expenses 200408 NCAA Division I intercollegiate athletic programs report. September. Indianapolis, IN: National Collegiate Athletic Association.

Fuoco, M.A. (2010). Colleges questioning steep price of winning in sports. Pittsburgh Post-Gazette. Retrieved from http://www.post- 
gazette.com/pg/09347/1020599-

449.stm.

Goff, B. (2004). Effects of university athletics on the university: A review and extension of empirical assessment. In J. Fizel and R. Fort (Eds.), Economics of college sports (pp. 65-86). Westport, CT: Praeger.

G. Gurey. (2014). President's message. The Drake Group, Inc. Retrieved from http://thedrakegroup.org/presidents -message.

Hoffer, A., Humphreys, B.R., Lacombe, D.J., \& Ruseski, J. (2015). Trends in NCAA athletics spending: Arms race or rising tide? Journal of Sports Economics, 16, 576-596.

Hoffer, A., \& Pincin, J.A. (2016) The effects of revenue changes on NCAA athletic departments' expenditures. Journal of Sport \& Social Issues, 40, 82102.

Huml, M.R., Hancock, M.G., \& Bergman, M.J. (2014). Additional support or extravagant cost? Student-athletes' perceptions on athletic academic centers. Journal of Issues in Intercollegiate Athletics, 7, 410-430.

Humphreys, B.R. (2006). The relationship between big-time college football and state appropriations to higher education." International Journal of Sport Finance, 1, 151-161.

Humphreys, B.R., \& Mondello, M. (2007). Intercollegiate athletic success and donations at NCAA Division I institutions. Journal of Sport

Management, 21, 265-280.

Jensen, M.C., \& Meckling, W.H. (1976).

Theory of the firm: Managerial

behavior, agency costs and ownership structure. Journal of Financial Economics, 3, 305-360.

Knight Commission on Intercollegiate Athletics. (2001). A call to action: Reconnecting college sports and higher education. June. Retrieved from

http://www.knightcommission.org/i mages/pdfs/2001_knight_report.pdf.

Knight Commission on Intercollegiate Athletics. (2004). New study debunks link among winning college athletic programs and increases in donations and quality of applicants. September 7. Retrieved from http://www.knightcommission.org/r esources/press-room/790september-7-2004-new-studydebunks-link-among-winningcollege-athletic-programs-andincreases-in-donations-and-qualityof-applicants.

Knight Commission on Intercollegiate Athletics. (2009). Quantitative and qualitative research with Football Bowl Subdivision university presidents on the costs and financing of intercollegiate athletics: Report of findings and implications. October. Retrieved from http://www.knightcommissionmedia 
.org/images/President_Survey_FIN

AL.pdf.

Knight Commission on Intercollegiate

Athletics. (2010a). College sports 101:

A primer on money, athletics, and higher education in the $21^{\text {st }}$ century.

Chapter 2: Expenses. Retrieved from http://www.knightcommission.org/i ndex.php?option $=$ com_content\&vie $\mathrm{w}=$ article\&id $=366 \&$ Itemid $=86$.

Knight Commission on Intercollegiate Athletics. (2010b). College sports 101: A primer on money, athletics, and higher education in the $21^{\text {st }}$ century. Chapter 9: Conclusion. Retrieved from http://www.knightcommission.org/i ndex.php?option $=$ com_content\&vie $\mathrm{w}=$ article $\& \mathrm{id}=374 \&$ Itemid $=94$.

Lanter, J.R., \& Hawkins, B.J. (2013). The economic model of intercollegiate athletics and its effects on the college athlete educational experience. Journal of Intercollegiate Sport, 6, 86-95.

Niskanen, W.A., Jr. (1971). Bureaucracy and representative government. Chicago, IL: Aldine Atherton.

Orszag, J.M., \& Orszag, P.R. (2005a). The physical capital stock used in collegiate athletics. April. Indianapolis, IN: National Collegiate Athletic Association. Retrieved from https://www.ncaa.org/sites/default/ files/physical_capital_stock_used_in _collegiate_athletics.pdf.

Orszag, J.M., \& Orszag, P.R. (2005b). The empirical effects of collegiate athletics: An update. April. Indianapolis, IN: National Collegiate Athletic Association. Retrieved from https://www.ncaa.org/sites/default/ files/empirical_effects_of_collegiate_ athletics_update.pdf.

Ross, S.A. (1973). The economic theory of agency: The principal's problem. American Economic Review, 62, 134-139. Sagas, M., \& Wigley, B.J. (2014). Gray area ethical leadership in the NCAA: The ethics of doing the wrong things right. Journal of Intercollegiate Sport, 7 , 40-57.

Sanderson, J., Hardin, R., \& Pate, J. (2014). Embracing the culture of winning in big-time college football: Exploring how fans reinforce coaching power. Journal of Issues in Intercollegiate Athletics, 7, 114-131.

Shubik, M. (1971). The dollar auction game: A paradox in noncooperative behavior and escalation. Journal of Conflict Resolution, 15, 109-111.

Smith,D.R. (2008). Big-time college basketball and the advertising effect: Does success really matter? Journal of Sports Economics, 9, 387-406.

Sparvero, E.S., \& Warner, S. (2013). The price of winning and the impact on the NCAA community. Journal of Intercollegiate Sport, 6, 120-142.

Stafford, L. (2010). College sports "arms race" not sustainable, say university presidents. Atlanta Journal Constitution. Retrieved from 
http://www.ajc.com/sports/collegesports-arms-race-273700.html.

Staurowsky, E.J., Murray, K., Puzio, M., \& Quagliariello, J. (2013). Revisiting James Madison University: A case analysis of program restructuring following so called "Title IX" cuts. Journal of Intercollegiate Sport, 6, 96-119.

Tsitsos, W., \& Nixon, H.L. (2012). The Star Wars arms race in college athletics: Coaches' pay and athletic program status. Journal of Sport \& Social Issues, 36, 68-88.

Tucker, I.B. (2004). A reexamination of the effect of big-time football and basketball success on graduation rates and alumni giving rates. Economics of Education Review, 23, 665-661.

Tucker, I.B. (2005). Big-time pigskin success. Journal of Sports Economics, 6, 222-229.

Tucker, I.B., \& Amato, L.T. (2006). A reinvestigation of the relationship between big-time basketball success and average SAT scores. Journal of Sports Economics, 7, 428-440.

USAToday (2015). NCAA finances. Retrieved from http://sports.usatoday.com/ncaa/fin ances.

U.S. Department of Education Office of Postsecondary Education (2015). The equity in athletics data analysis cutting tool. Retrieved from http://ope.ed.gov/athletics.

Weight, E., Navarro, K., Huffman, \& Smith-Ryan, A. (2014). Quantifying the psychological benefits of intercollegiate athletics participation. Journal of Issues in Intercollegiate Athletics, 7, 390-409.

Weight, E.A., Weight, M.A., \& Schneider, R.G. (2013). Confronting the arms race: Conference commissioner perspectives on spending within intercollegiate athletics. International Journal of Sport Management, 14, 441 461.

Weingast, B.R. (1984). The congressionalbureaucratic system: A principal agent perspective (with applications to the SEC). Public Choice, 44, 147191.

Weingast, B.R., \& Moran, M.J. (1983). Bureaucratic discretion or congressional control? Regulatory policymaking by the Federal Trade Commission. Journal of Political Economy, 91, 765-800.

Women's Sports Foundation. (2008). Dropping men's sports - The Division I football/basketball arms race is the culprit in the cutting of men's Olympic sports: The foundation position. Retrieved from http://www.womenssportsfoundatio n.org/home/advocate/title-ix-andissues/title-ixpositions/football_basketball_arms_r ace. 


\section{Table 1}

\section{Tables}

Top 25 Revenues, 2013-14

\begin{tabular}{ll}
\hline Department & Total Revenue \\
\hline Texas (Big 12) & $\$ 161,035,184$ \\
Alabama (SEC) & $\$ 152,588,651$ \\
Ohio State (Big Ten) & $\$ 143,718,564$ \\
Michigan (Big Ten) & $\$ 135,869,791$ \\
LSU (SEC) & $\$ 132,828,429$ \\
Oklahoma (Big 12) & $\$ 129,220,692$ \\
Wisconsin (Big Ten) & $\$ 124,928,916$ \\
Auburn (SEC) & $\$ 120,699,075$ \\
Florida (SEC) & $\$ 118,860,545$ \\
Penn State (Big Ten) & $\$ 117,590,993$ \\
Notre Dame (Indep) & $\$ 114,843,522$ \\
Stanford (Pac 12) & $\$ 110,240,490$ \\
Southern California (Pac & $\$ 106,528,649$ \\
Iowa (Big Ten) & $\$ 105,508,954$ \\
Florida State (ACC) & $\$ 104,420,339$ \\
Tennessee (SEC) & $\$ 103,542,112$ \\
Georgia (SEC) & $\$ 103,495,587$ \\
Minnesota (Big Ten) & $\$ 100,707,642$ \\
Washington (Pac 12) & $\$ 100,275,186$ \\
South Carolina (SEC) & $\$ 98,439,097$ \\
Kansas (Big 12) & $\$ 97,681,067$ \\
Arizona (Pac 12) & $\$ 97,630,769$ \\
Arkansas (SEC) & $\$ 96,793,972$ \\
Nebraska (Big Ten) & $\$ 94,797,692$ \\
Kentucky (SEC) & $\$ 92,842,049$ \\
ACC & \\
Big 12 & 1 \\
Big Ten & 3 \\
Indep & 7 \\
PEC & 1 \\
Total & 9 \\
Pac & 25 \\
\hline
\end{tabular}

Source: Total revenue data are from U.S. Department of Education Office of Postsecondary Education (2015).

Journal of Amateur Sport Special Issue: Political Economy $\quad$ Fort, 2016 

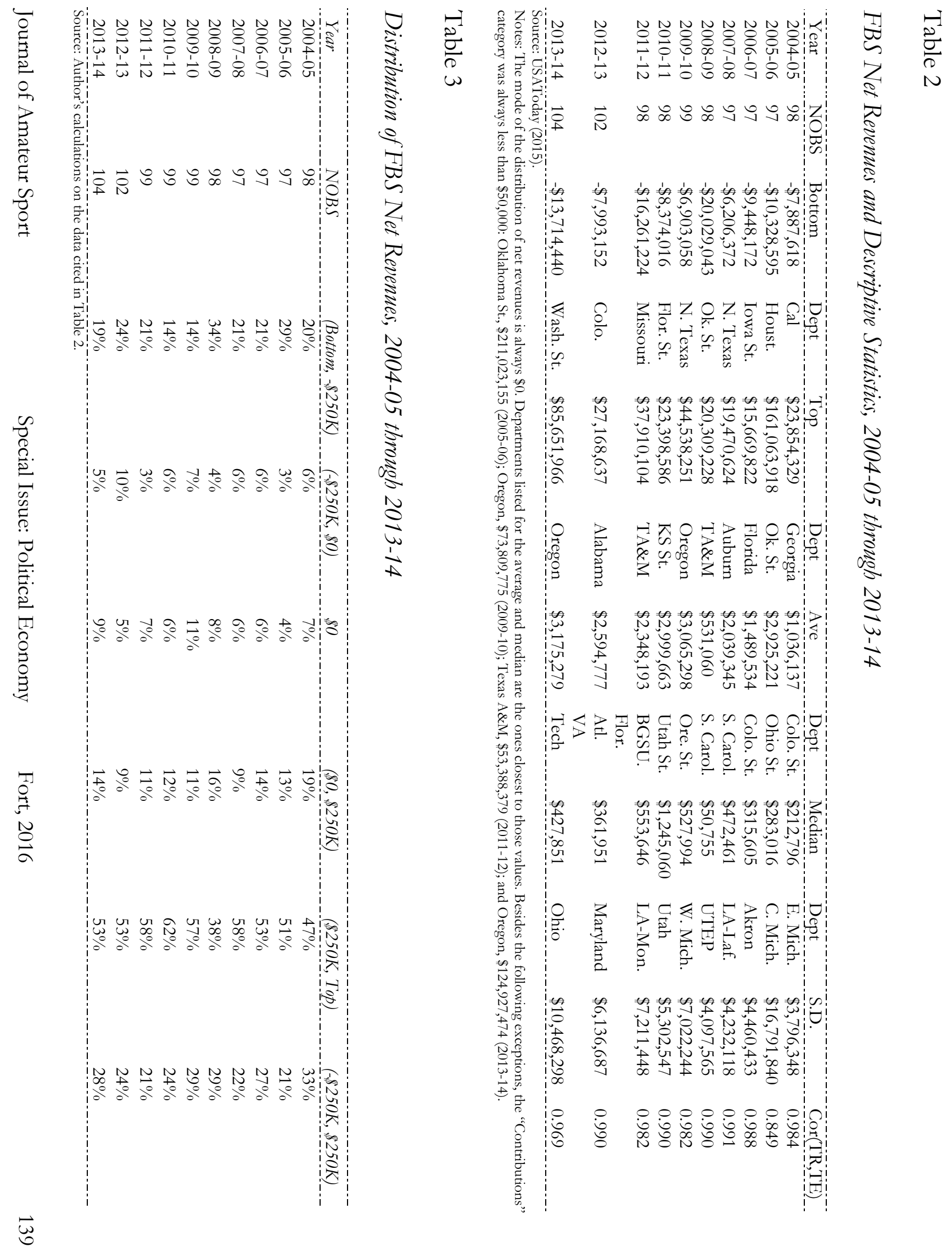


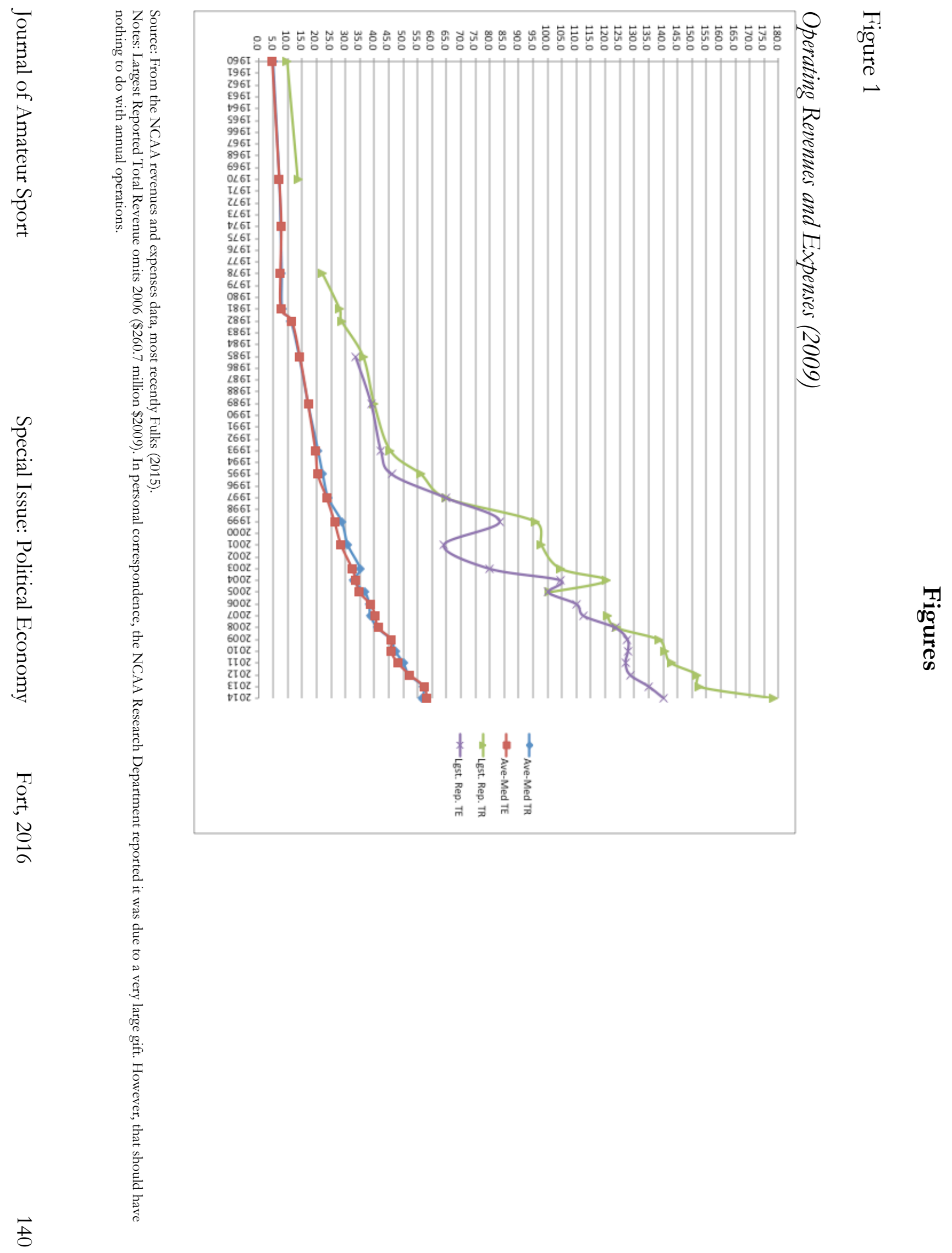

